\title{
The Holocaust in the National Curriculum after 25 Years
}

\author{
Andy Pearce
}

Centre for Holocaust Education, Curriculum, Pedagogy \& Assessment, UCL Institute of Education, London, United Kingdom

Postal address: Centre for Holocaust Education, UCL Institute of Education, Level 1, 23-29 Emerald Street, London, WC1N 3QS.

Email: a.pearce@ucl.ac.uk

Andy Pearce is a Lecturer in Holocaust and History Education at UCL's Centre for Holocaust Education, where he teaches a national, research-informed programme of Continuing Professional Development (CPD) for serving and trainee teachers. He is also involved with the Centre's research activities, and is a lead author of its landmark student research What do students know and understand about the Holocaust? Evidence from English Secondary Schools. Andy researches and writes on issues related to teaching, learning and remembering the Holocaust in Britain and beyond. He is the author of Holocaust Consciousness in Contemporary Britain (2014), is currently editing Remembering the Holocaust in Educational Settings (2018), and is co-editing with Tom Lawson The Palgrave Handbook on Britain and the Holocaust (2020). Andy has acted as a consultant for Government, collaborated with national institutions such as the Imperial War Museum and the Wiener Library, and has worked with media organisations like the BBC. He is the Reviews Editor of Holocaust Studies: A Journal of Culture and History. 


\section{The Holocaust in the National Curriculum after 25 Years}

This article provides a historical overview of the position of the Holocaust within the National Curriculum since 1991. Through close analysis of the five iterations of the curriculum, it traces changes and continuities in how teaching and learning about the Holocaust has been stipulated by successive governments. By contextualising these with reference to shifts in England's Holocaust culture, it is shown that the National Curriculum has acted as a fulcrum for the evolution of Holocaust consciousness. However, it is also argued that many of the faults and failures, challenges and shortcomings within the National Curriculum are symbiotic and closely entwined with wider issues in Britain's Holocaust culture.

Keywords: Holocaust; Holocaust education; National Curriculum; England; Britain; Holocaust memory.

“"Would you tell me, please, which way I ought to go from here?'

'That depends a good deal on where you want to get to,' said the Cat.

'I don't much care where -' said Alice.

'Then it doesn't matter which way you go,' said the Cat.

'-so long as I get SOMEWHERE.' Alice added as explanation.

'Oh you're sure to do that,' said the Cat, 'if you only walk long enough."'1

- Lewis Carroll, Alice's Adventures in Wonderland

The history of teaching and learning about the Holocaust in the United Kingdom over the past generation is a story of success, achievement, and change. It is also a history of failure, shortcomings, and inhibiting continuities. As such, the ways educators have taught and students have learnt about the genocide of Europe's Jews over the last three decades suitably reflects and embodies the long-standing characteristics of British - or, more specifically English - Holocaust consciousness. ${ }^{2}$

At the centre of this chronicle is the National Curriculum. ${ }^{3}$ Ever since the first 
curriculum of 1991 the Holocaust has been named within the rubric of the History syllabus. Not only has it survived periodic revisions of the curriculum, but each new iteration has in fact enhanced its status. Furthermore, though the Holocaust has only ever been a mandatory requirement in the National Curriculum for history, over the last 25 years other subjects have increasingly broached the subject as well. The primary benefits of these developments have been two-fold - contributing to a significant expansion in the level of awareness among a generation of young people, and helping to invest "the Holocaust" as a cultural concept and social construction with considerable semiotic power. These advances have such salience because of the haphazard way in which the Holocaust was taught prior to 1991, and the generally underdeveloped condition of Holocaust culture in Britain during the first three decades after 1945.

The education system has thus played a central role in the formation of a Holocaust culture in the United Kingdom - particularly in England, which is the focus of this article. ${ }^{4}$ It is here that the National Curriculum has reached millions of schoolchildren, and in turn had the greatest impact in shaping Holocaust consciousness. Reflecting on how and why this has been the case, as well as the types of historical thinking the curriculum has inculcated, is only more apposite given the academisation of the English education system. The ability of academies and free schools to choose the structure and content of their curricula has contributed to the strange and slow death of a truly national curriculum in England, but in the process it has fundamentally eroded the idea of teaching and learning about the Holocaust being a statutory requirement of statemaintained schools. With the number of academies and free schools increasing dramatically since 2010, and the current government quite open about its wish for all schools to become academies, the future position of the Holocaust in school curricula is in jeopardy. ${ }^{5}$ 
Outwardly, at least, central government presently maintains "that every young person should be taught the history of the Holocaust and the lessons it teaches today". 6 The latter part of this aspiration is, of course, extremely contentious: amongst other things, analogous thinking "wrongly assumes the past is a given". ${ }^{7}$ For those who believe in and want there to be "Holocaust lessons", such realities can be easily ignored. Increasing young people's historical knowledge and understanding on the other hand might not be straightforward, but it is desirable for the pursuit of "critical being" and arguably more justifiable as a tangible pedagogical endeavour. ${ }^{8}$

For the time being, most students continue to encounter the Holocaust as part of their formal education and commonly within school history - often because their schools choose to follow the National Curriculum. The nature of these encounters, the effect and impact they have on student's knowledge and understanding of the Holocaust, are altogether different matters. As the research showcased in this Special Issue demonstrates, for all the interest and enthusiasm students demonstrate towards learning about the Holocaust, the condition of their substantive historical knowledge and the shapes of their conceptual understandings give much cause for concern. ${ }^{9}$ Some of the shortcomings in students' knowledge are in fact so elemental, and some of their understandings so fundamentally wrong, that one is forced to question how this can be possible after a generation of State-sponsored teaching in schools. When one also factors in the considerable sums of public treasure invested in "Holocaust education" by successive governments and the gamut of extracurricular activities in culture more broadly, the resonance of these research findings is only louder, clearer, and more disturbing to the ear. They pose compelling questions about the nature of teaching and learning about the Holocaust in this country: its core precepts, its central aims and intended outcomes, and how far the popular understandings of "Holocaust education" 
are suitably cognisant of what teaching and learning actually entail.

The principal purpose of this article is to provide an overview of the history of the Holocaust in the English curriculum over the last quarter of a century. Its focus will be on how the Holocaust has been positioned and framed within National Curriculum, and the ways this has or has not altered since 1991. The analysis approaches the curriculum and its stipulations in two registers: as a policy statement and programme for action on the one hand, and as a representational (and representative) entity on the other. Through these lenses we acquire insight into the thinking of the governments of the day, and perspective on the cultural standing of the Holocaust at any given time. In working towards these outcomes the article thus serves a secondary purpose: it weaves a backcloth onto which the other articles of this Special Issue can be juxtaposed and viewed. Some of the themes and issues it presents are taken up by others in this collection; these include knowledge, the relationship between the realms of education, culture and society, and questions of pedagogy - in particular, purpose and practice.

Ambiguity over aims and confusion over rationale are hallmarks of the history of the Holocaust in the curriculum. One might say uncertainty as to why the Holocaust should be taught has led to much drift and dawdle: research shows that, when teaching about the Holocaust, teachers have a penchant for nebulous, generalised, overarching learning objectives instead of ones more suited to their subject discipline, and they are dismissive of the possibility - even the need for - exercises in evaluation or assessment. ${ }^{10}$ Meanwhile the championing of cross-curricular and whole school approaches to teaching the Holocaust, both by teachers, NGOs, and MPs, ${ }^{11}$ has tended not to be accompanied by substantial theorisation about subject disciplinarity or coherent planning. ${ }^{12}$ The result is students speak of the importance of "the Holocaust" and their eagerness to know more, all the while constructing reductive narratives about 
what "it" was, and exhibiting rudimentary understandings shorn of criticality.

At the same time, the spaces created by the Holocaust in the curriculum have allowed particular approaches and conceptions of what "Holocaust education" is and entails to be popularised. This helps account for the desire of most teachers that their students "learn the lessons" of the Holocaust ${ }^{13}$ a laudable objective, perhaps, but one risking essentialism. ${ }^{14}$ Still, it would be unfair to blame teachers alone for this tendency, when it is one with immense cultural currency and political capital. Here then is the nub, for within the discourse popularised by politicians, commentators, and even some working in the field, there is often little to no space for pedagogy; instead of contemplating the intricate and complex ways in which teaching and learning interface, the compulsive and unthinking assumption is that it is enough just to have the Holocaust in the curriculum - as if this guarantees it will be "taught" and, in some osmotic fashion, subsequently "learnt". Like Alice in Wonderland then it is as if it doesn't really matter what we teach, how, or why, so long as somewhere, somehow, students are exposed to what the late David Cesarani depicted as the "standardized version" of "the Holocaust". ${ }^{15}$ This, it seems to be presumed, will be enough to ensure they "Never Forget", intone "Never Again" and become better, nicer people. Such flawed thinking is not solely attributable to the National Curriculum, but that it exists at all raise serious questions about the history of the Holocaust in the curriculum and British culture at large.

\section{Conceptualising curricula}

It is important from the outset to establish the nature of curricula. Far from having singular, immutable meaning, "curriculum" and "curricula" have multiple connotations reflective of their employment in a wide-range of contexts. At its most fundamental and 
exclusive, curriculum can be defined as "simply the learning experiences that are planned within the school". ${ }^{16}$ The accent placed on intent is key, for what is planned is not necessarily commensurate with what is delivered or received. ${ }^{17}$ As important as recognising and delineating between intended and actual learning experiences is the need to acknowledge the existence of the "hidden" curriculum: that "tacit teaching to students of norms, values, and dispositions that goes on simply by their living in and coping with the institutional expectations and routines of schools" ${ }^{18}$ Curriculum can therefore be opened up even further, and used to refer to (and distinguish between) formal and informal teaching and learning - what happens at the chalkface, and what occurs outside the classroom.

For all its multifarious manifestations, curricula are culture-bound. To be more precise, curricula do not just have "cultural" dimensions and dynamics, but are rather an explicit expression of culture. In the famous words of Denis Lawton, "the school curriculum (in the widest sense) is essentially a selection from the culture of a society"; ${ }^{19}$ thus prompting the "very fruitful, but occasionally obvious question...'Who selects? ${ }^{, 20}$ Power and politics therefore rest at the very core of curricula - regardless of the particular key it is tuned in - and "those responsible for making the selection have a duty to demonstrate that it is neither arbitrary nor idiosyncratic". Consequently, Lawton asserts, whatever is selected has to be "open to rational enquiry and justification, not least because complete agreement about the curriculum will rarely be possible". ${ }^{21}$

Positioning curriculum as cultural politics allows us to see that "all curriculum decisions are cultural decisions...struggles over curriculum are ultimately struggles about culture". ${ }^{22}$ This comes sharper into view when we consider the functions curriculum performs. By the lights of Basil Bernstein, curriculum provides a riposte to Herbert Spencer's query "what knowledge is of most worth", by defining "what counts 
as valid knowledge". Bernstein emphasises this process of demarcating "educational knowledge" is entwined with "the distribution of power and the principles of social control", for educational knowledge comes to operate as "a major regulator of the structure of experience". ${ }^{23}$ This means educational knowledge has the capacity to "create endlessly new realities" and so can give "a special significance to those who possess it". ${ }^{24}$

In working as a "disciplining technology that directs how the individual is to act, feel, talk and 'see' the world and 'self", curriculum can be described as "a governing practice". ${ }^{25}$ As a codified statement of power, it stipulates what should be known and privileges this as "official knowledge". Yet, as Michael Apple notes, "the politics of official knowledge are the politics of accords and compromises". ${ }^{26}$ Since elites are not the sole proprietors of official knowledge, it becomes essential to understand curriculum as what Michael Young calls a "social fact": that is, "a structure that constrains" those who use and have vested interests in it, and one which equally "make[s] some things possible to learn that most of us would find impossible to learn without" it. ${ }^{27}$

The capacity to simultaneously constrain and enable means curriculum is "never just a 'relay' of society. It 'reproduces' or 'relays' social relations from the wider society but not in any mechanistic way; it is also a 'relay' itself with its own structures". ${ }^{28}$ Since the shape, form, and content of a curriculum speak of the social collective, it can be taken as a statement on the overarching purpose of education. Ideas and ideologies about education are of course "value-based belief systems", ${ }^{29}$ which "may not exist in a pure form' and can 'overlap and indeed interact". ${ }^{30}$ Even so, within any educational ideology some principles are foundational.

One such ideology is termed "classical humanism", and is predicated on the precept of "cultural heritage". ${ }^{31}$ Within this structure, "education is about knowledge 
and understanding" and becomes an "initiation" into "the forms of knowledge that are represented by long-established subjects". ${ }^{32}$ In contrast to this tradition is what might be called "progressivism", where "the transmission of cultural heritage is abandoned in favour of the goal of the child discovering for himself and following his own impulses". ${ }^{33}$ Within a progressive educational outlook the child is central in every sense; even the value of subjects and subject knowledge "depends" in Richard Pring's words "on what the value the child finds in it to help him or her live a fulfilled and satisfying life". ${ }^{34}$ Finally, a third ideology is what Lawton depicts as "reconstructionism". Here education is utilitarian and socially transformative; accordingly, curricula is either imbued with "social values" and "experiences appropriate for developing citizenship and social cooperation", ${ }^{35}$ or it is geared towards functionality - what Pring calls "the useful curriculum - one that produces the knowledge, the skills and the attitudes necessary for the world of work". ${ }^{36}$

Any curricula can be infused with one or more of these ideologies, meaning the ideological calibration of a curriculum reflects the constellations of power and influence around it. In the case of the Holocaust curricula, these tend towards some sort of amalgamation of classical humanism and reconstructionism. Out of both belief in the importance of knowing about the Holocaust and a fear of forgetting, emphasis is often placed on transmitting "knowledge" to learners. At the same time, knowing about the Holocaust is invariably regarded as having utility - usually for moral, ethic, or civic ends. Because of the dominance of these two ideologies within Holocaust curricula, there is commonly a reticence towards progressive approaches to pedagogy, with childcentred learning and social constructivist methods eschewed for more traditional forms of teaching. 


\section{Curriculum in England pre-1991}

This brief sojourn into conceptualising curricula underlines its complexity and intractability from the spheres of culture, politics and society. These features mean curricula are not fixed and immutable, but malleable and fluid, reflecting how curriculum is in the words of John White "a vehicle, or collection of vehicles, intended to reach a certain set of destinations". ${ }^{37}$ Accordingly, moments of curriculum change or revision suggest juncture, and poses questions of who, how, and why.

The passage of the Education Reform Act (ERA) in 1988 was one such instance. "The most wide-ranging and revolutionary piece of educational legislation in English history", ${ }^{38}$ the ERA completed the breakdown a consensus over the aims, purpose, and organisation of education in England that had been in place since 1945. For three decades the English education system was wedded to the post-war welfare settlement, with education seen as instrumental in economic development and social equality. ${ }^{39}$ With the 1944 Education Act had come a tripartite division of schools according to type (grammar, technical, secondary modern) and the introduction of free universal schooling for all. Responsibility was devolved from the centre, leaving Westminster to assume a "guardian" role but otherwise follow a policy of non-interference. ${ }^{40}$ Crucially this extended to curriculum: matters of content and pedagogy were, by and large, the purview of schools and schools alone. ${ }^{41}$

For a variety of reasons this state of affairs came under increasing attack from the 1960s onwards. To ideologues, a perceived decline in standards was attributable to comprehensive education and a collapse in discipline and behaviour could be pinned on teachers - most of whom, it was presumed, held left-wing views of the world. ${ }^{42}$ In short, there was what Sally Tomlinson frames as a demonization of the education settlement in the late 1960s; one involving both left and right of the political spectrum, founded on 
the notion that "progressive education supposedly caused irreversible decline", ${ }^{43}$

Overarching this narrative was growing anxiety about the future, about Britain's postimperial place and role in an ever-more unpredictable world. Such fears were only further stoked by the economic turbulence and social disruption of the 1970s.

The pre-history to the ERA goes some way to explaining its occurrence and highlighting its radicalism. The belief schools had "disintegrated into chaos" 44 became political orthodoxy with the success of Thatcherism in the late 1970s, enmeshing with belief in the need to implement "an economic market doctrine" in education. ${ }^{45}$ The ERA embedded these principles. Through it came "a fundamental shift" from "licensed autonomy" to "regulated autonomy". ${ }^{46}$ Parental choice was prioritised, local control fatally undermined (and in some respects, completely removed), and Darwinian competitiveness championed.

At the centre of this new alignment was the introduction of a National Curriculum to be followed by students aged 5-16 years old in all governmentmaintained schools. The intent was for "a balanced and broadly based curriculum" promoting "spiritual, moral, cultural, mental and physical development", and preparing students "for the opportunities, responsibilities and experiences of adult life". ${ }^{47}$ Comprised of Core Subjects (English, Maths, Science), and Foundation Subjects (History, Geography, Art, Technology, Music, a Modern Foreign Language, and Physical Education), schools would decide curriculum timetabling with the expectation two-thirds of the time would be given over to the Core Subjects. ${ }^{48}$ Subjects would be delivered across four age-related Key Stages, with specified attainment targets stipulating what students were to know and understand at particular ages, and related Programmes of Study containing prescribed subject content. 
The National Curriculum was to be implemented in stages from 1989 through to the early 1990s. It was inherently traditional in structure - "traditional", that is, in its conception of knowledge as "external to the learner" 49 and "its division into subjects and in the very nature of those subjects themselves". ${ }^{50}$ Since it was "an assessment-led curriculum"51 it promoted "didactic, teacher-centred modes of instruction", for these "are more efficient for accomplishing the goal of disseminating information and insuring that predetermined learning objectives are met". ${ }^{52}$

There was therefore considerable ideological work embodied within the National Curriculum - unsurprisingly so, given the preoccupations of the government of the day. As Keith Crawford had it, "the traditional, subject-based curriculum was to be the vehicle through which national cultural and moral values could be defended". ${ }^{53}$ However, the underlying articulated rationale of the National Curriculum was distinctly inchoate. For some, like White, the aims as outlined in the ERA were but "bland truisms" with little to say about why the subjects selected should be pursued. ${ }^{54}$ Rhys Griffith meanwhile found "the enlightened (some might say, inflated) purpose of the National Curriculum" not commensurate with "the typical school experience of most secondary school pupils" - inevitably, perhaps, since "this knowledge-based, assessment-driven curriculum demands didactic drill-training to ensure examination success...such pedagogy suppresses the development of a critical disposition". ${ }^{55}$

\section{Teaching the Holocaust before the National Curriculum}

In the short-term, teachers and schools faced more pragmatic problems. The curriculum was heavily overloaded and assessment procedures highly controversial, leading just a few years later to the outbreak of hostilities between teachers, schools, and the government. The government's response was the Dearing Review of the curriculum, conducted during 1993-1994 and leading to a second version of the National 
Curriculum in 1995. But before turning to examine the place of the Holocaust in the two Conservative curriculums of 1991 and 1995 it is valuable to establish the condition of teaching and learning about the Holocaust prior to the ERA.

The nature of the English education system between 1945 and 1988 outlined previously is especially relevant here. We've noted how during this period schools and teachers were masters of their own curricula; masters who remained, of course, inseparable from post-war British culture, society and politics. This rootedness goes a long way to explaining the curriculum choices made by institutions and individuals. For example, it helps account for why much school history in the immediate post-war decades was informed by an "inherited consensus" wherein anything that wasn't “essentially Anglocentric history", struggled to find a place. ${ }^{56}$

The general absence of the Holocaust from English school curricula in the 1950s and 1960s is to be explained then by the subject's standing within British historical culture at this time. ${ }^{57}$ Yet some caution is wise here. We should not presume the topic was never broached or referred to (however tangentially) in schools. Although it did not constitute the "shadow" it did elsewhere, the "latency" of the Holocaust in the post-war decades was a pan-European phenomenon and Britain was not untouched by this. ${ }^{58}$ It would be naïve to assume its varying degrees and forms of socio-cultural presence in these years did not filter through into the school environment. What can be claimed with reasonable assurance is this rarely, if ever, translated into focused, organised teaching and learning.

As "cultural workers" teachers have the capacity to affect change but are not impervious to the prevailing winds of the day. ${ }^{59}$ For the first thirty years after the war these gusts only brought the destruction of European Jewry to the forefront of nonJewish consciousness sporadically, and even then rarely in a fashion which recognised 
the specific dimensions of the Jewish experience. Major deficiencies in public knowledge and understanding had a part to play, as did the influence of rose-tinted war memories and the persistence of the "liberal imagination". ${ }^{60}$ But to this must be added the sense that the fate of the Jews, as terrible as it was, was seen to have little relevance or priority for a country grappling with the challenges of decolonisation and social change.

A further curtailment during these years was the lack of a collectively shared organizing conceptual framework, into which the events of the Holocaust could be posited in ways that did not efface its distinctive characteristics. This was not about "the Holocaust" being absent from common parlance; even when the phrase grew in cultural circulation in Britain after the 1970s, its point of reference (let alone its meaning) continued to be contested and debated throughout subsequent decades. Furthermore, in the first three decades after 1945, there emerged a "social norm" against genocide: ${ }^{61}$ a paradoxical development, not least in light of the tendency of successive British governments to repeatedly find ways of not acceding to the UN Genocide Convention.

The potency of this "social norm" within civil society was measurable during the 1950s, 1960s and 1970s by the regular media references to "genocides" taking place around the world. Sometimes, as with the Nigeria-Biafra conflict of the late 1960s, public "associations with the Holocaust became especially virulent". ${ }^{62}$ A language (however flawed) did exist then for talking about the Jewish experience, but this was used with varying degrees of sophistication and interest. Nor did this language necessarily translate into shared understanding, either of what was being spoken of or about, or how its contours related to other instances of human atrocity. Since the "social norm" against genocide was marked by its broad, inclusive approach, it did not easily allow for the assertion of particularities. ${ }^{63}$ 
With Britain's cultural turn to the Holocaust from the 1970s came a series of interrelated developments: slow, but steady, increases in representational work, heightening public intrigue, advances in popular knowledge and understanding, and a cultural structure named "the Holocaust" - a porous framework far from being at any advanced stage of maturation, but an edifice nonetheless. We cannot date when teachers decided to draw on this frame and incorporate the Holocaust formally into their curricula, but the decision of cultural institutions like the Imperial War Museum to hold school talks in the late 1970s touching on aspects of Jewish life in Nazi Germany indicates emerging demand. The same is true of various public exhibitions staged during the 1980s - many of which were designed with schoolchildren in mind - as well as the considerable popularity of teaching materials created by the Inner London Education Authority (ILEA) in the mid-1980s. ${ }^{64}$

In the late 1980s anecdotal indications of an upturn in teachers' interest in the Holocaust were augmented by empirical research. Conducted under the auspices of the Yad Vashem Charitable Trust UK (YVCT), John Fox drew on a sample of over 249 respondents from Local Education Authorities (LEA) in England and further education institutes to questionnaires exploring coverage of and attitudes towards teaching the Holocaust; primarily in history. Encouragingly, Fox discovered the Holocaust was being taught in schools, and on occasions included within public examinations. Less welcome was how teachers tended not to view the Holocaust as a particularly "special subject" and were quite stridently opposed to such a treatment; partly, perhaps, as many perceived it to be synonymous "with things Jewish". ${ }^{65}$ Intriguingly - given the form much Holocaust education would later assume - Fox also found significant gaps and misconceptions in subject knowledge, and a tendency towards reducing the Holocaust to "the level of an abstract "concept". ${ }^{66}$ 
As "a panorama onto teacher attitudes and teaching practices", the Fox report indicated change had occurred from previous decades. ${ }^{67}$ Some, but by no means all, school history departments were now choosing to include the Holocaust in their curricula. For Susan Hector, had Fox widened his gaze "he would have noticed that the Holocaust was being taught in a number of departments" such as English and Religious Education, suggesting a sizeable proportion of educators believed the subject had importance and value. ${ }^{68}$

It would be wrong though to overinflate the advances made during the 1980s. As Fox found, "in many educational quarters - and therefore by implication in much of British society as well" misconceptions and negative attitudes were active, just as hundreds of thousands of students still did not study the Holocaust in their formal schooling. ${ }^{69}$ Whilst the introduction of the National Curriculum would start to address some of these issues, it did not necessarily alter them all.

\section{The Holocaust in the first National Curriculum}

By no means did the advances of the 1980s render the subject well-positioned when it came to devising the content of the National Curriculum. For that task subject working groups were charged with devising Programmes of Study and related Attainment Targets. In the case of history - the subject where the Holocaust was most likely to be found in school curricula - the History Working Group (HWG) formed in January 1989 quickly found themselves caught between especially sharp rocks and brutally hard places. Put simply, "history in the National Curriculum attracted more controversy and public attention than any other subject"; content was intensely debated and publically debated, and there were fundamental differences in how the group and the government understood the purpose and nature of history education. ${ }^{70}$ Just how politicised this state of affairs was could be seen by the level of direct interference by Thatcher, through the 
Secretary of State, to force the HWG to "modify" its draft proposals to "give more attention to chronology" and "more British history". ${ }^{71}$

Published in August 1989, the HWG's draft proposals did not include the Holocaust. Given the dominant educational ideologies of the time and the wider condition of British Holocaust consciousness, this was not at all shocking. Throughout the United Kingdom the Holocaust was still not the "issue" it was becoming on the continental mainland or beyond. The outbreak in the late 1980s of public controversy around Nazi war criminals living in Britain was generating considerable interest, forming an important backdrop to the National Curriculum and spawning the educational pressure-group the Holocaust Educational Trust (HET) ${ }^{72}$ However spiky as the war crimes affair was though, it was not controversial enough to force the HWG to reconsider its proposals.

Ultimately the HWG's decision to not give the Second World War a "separate space of its own" provided campaigners with the opportunity to promote the Holocaust as a school subject. ${ }^{73}$ Within the HWG it was felt "a curriculum for the twenty-first century did not absolutely require the inclusion of the rise and fall of Nazi Germany", and there was concern over British obsession with the conflict and its growing abstraction. ${ }^{74}$ As a concession to teachers who might want to cover Nazism the HWG proposed an optional unit of "the rise and fall of Nazi Germany", but this was not necessarily understood by the Group as shorthand for teaching about the Holocaust. ${ }^{75}$

The suggestion the Second World War was only optional learning was vociferously condemned in the public sphere, but not - generally speaking - on account of any bearing this might have on teaching the Holocaust. That line of attack was instead championed by a much smaller collective of people: principally, "the Jewish community, with the support of sympathetic non-Jewish MPs" in what Tony Kushner 
calls "a remarkable display of ethnic lobbying". ${ }^{76}$ As well as "careful behind-the-scenes lobbying"77 formal submissions were made to the Secretary of State by the YVCT, the HET and a group of cross-party MPs. Of these, the latter was characterised by how it explicitly tied the Holocaust to self-congratulatory British war memory, diplomatically positioned the specific experience of the Jews in relation to multiple other victim groups, and cast this history as exemplar for "insight into the suffering experienced by minority groups in many parts of the world today". ${ }^{78}$ The submissions were also followed-up in parliamentary debate - a move which antagonised the HWG, and led to direct attempts by the Department of Education and Science to ensure the subject would be included in the HWG's Final Report. ${ }^{79}$ The eventual inclusion of the Holocaust in the HWG's Final Report of January 1990 spoke to the success of these efforts, though it would be incorrect to see the group as completely at the whim of campaigners and politicians. $^{80}$

Under the HWG proposals the Key Stage 4 (14-16 year olds) Programme of Study contained a compulsory unit on "The Era of the Second World War, 1933-1948”. The Holocaust - or rather "Genocide: the Holocaust" - was contained in a somewhat eclectic list of core knowledge ("essential information") to be taught, with "Auschwitz" named among stipulated "exemplary information". ${ }^{81}$ But in spite of how politicised the work of the HWG had been, its Final Report was not gospel. Its recommendations had to be endorsed by the National Curriculum Council, and approved by the Secretary of State, ${ }^{82}$ at that time, Kenneth Clarke. Clarke's insistence in late 1990 that history become an optional subject after the end of Key Stage 3 (11-14 year olds) meant the recommended curriculum was "upset and disarranged - indeed, decapitated". As a result, the entire Twentieth Century syllabus (of which the Holocaust's Core Study Unit 
was a part) was severed from the Key Stage 4 curriculum, and unceremoniously dumped into Key Stage 3. ${ }^{83}$

\section{The Conservative curricula - 1991 \& 1995}

In this inauspicious fashion teaching and learning about the Holocaust became a compulsory subject in State-maintained schools from September 1991. Recalling how charged debates around the history curriculum had been and the reality the Holocaust was of only marginal interest to most people, it was quite astonishing. For campaigners it was an achievement no doubt, but not one without some considerable issues.

The most immediate matter was pragmatic. Thanks to the last minute surgery, the Key Stage 3 curriculum was simply too bloated to be taught in anything like an effective way. With insufficient time to adequately cover all of the content, teachers inevitably cut corners - either in terms of superficially covering certain topics, or simply leaving them out altogether. With the Holocaust, both scenarios applied. ${ }^{84}$ It is possible that those negative attitudes unearthed by Fox played a part here, though we cannot be sure; far clearer was how a proportion of the teaching profession did not relish teaching the subject. There was frustration and annoyance at how it had been shoehorned into Key Stage 3, doubt as to whether this was an appropriate age to even teach the Holocaust, and a lack of both confidence and expertise in handling the subject matter. ${ }^{85}$

A related raft of challenges concerned pedagogy. A few years after the new history curriculum came into force, research by Geoffrey Short found teachers were beginning to warm to the topic, but around a third remained unconvinced of its suitability for Key Stage 3. ${ }^{86}$ A number also indicated curriculum overload compromised the amount of time they could spend on the subject, with knock-on effects for teaching approaches. Consequently, there was propensity to avoid contextualisation 
and spend no real time exploring the history of antisemitism. ${ }^{87}$ But pedagogy was not bent just by time constraints. A limited availability of resources, low expectations about what was achievable with such young students, and significant holes in teachers' own subject knowledge also conditioned teaching too.

All told, Short found teachers struggling with "conveying the reality, scale and enormity of the Holocaust". He also discovered many were employing a questionable rationale: though "the vast majority... are committed to Holocaust education", he wrote, the tendency was to "see its value in terms of combating racism rather than antisemitism" ${ }^{88}$ Using the Holocaust for such ends may have sounded well-enough - it gave the subject potentially wide appeal by making it appear universal, yet it meant students were unlikely to grasp its historical particularities or come to grasp its specific causal factors.

These pedagogical problems were intractable from and a product of the overarching challenge of the first National Curriculum: that is, deciphering just what the government actually saw as the purpose of teaching the Holocaust. This had a wider context. Matthew Pearson observes how from the outset "one of the manifest problems with the National Curriculum is the level at which its discourse operates", and the 1991 version certainly preferred "the general to the specific". It equally avoided "fine detail" and any "substantive amplification of how exactly schools should go about the rather difficult business of designing content to achieve this knowledge". ${ }^{99}$ In so doing, the curriculum revealed the particular ideological foundations on which it rested.

The structural condition of the National Curriculum helps explain how the Holocaust was eventually outlined in Key Stage 3 History. Its home unit was finally entitled "The Era of the Second World War", with content sub-divided into three themes: developments in Europe in the 1930s, "the experience of war" and immediate 
consequences. ${ }^{90}$ Under the second of these appeared the words "the Holocaust", sandwiched between "the home front" and "the dropping of the atomic bombs". Unlike the HWG's proposals there was no further indication of essential or exemplary information; no reference to "Genocide" as a substantive concept, or to "the Holocaust" as being a "historical or technical" term. ${ }^{91}$ Instead, 'the Holocaust' simply appeared, hanging in almost suspended animation. It was a practice in keeping with the "content approach" of the 1991 curriculum. $^{92}$

Including the Holocaust in the history curriculum signified the government's belief in its importance. It had become, in Bernstein's formulation, “educational knowledge". Yet its framing rendered it as "objectified knowledge" 93 to be transmitted, bound exclusively within the subject of history, and - it seemed - without purpose or meaning beyond intellectual development. So framed, mandatory teaching of the Holocaust was thus gravely weakened by an elemental faux pas, for as Lawton notes "any national curriculum has to be a compromise between two extremes: if curriculum are too general they will be untestable, but if they are too specific they become trivial". 94

The overt generality of the Holocaust's framing did indeed lead to complications over assessment, but the root cause of the problem was the lack of an explicit raison d'être, leaving teachers to conjure this for themselves. That defect was attributable to the structuring of the curriculum, but it was equally an expression of governmental uncertainty about what the Holocaust was, its relation to Britain, and how it was to be used. Yet the government was not alone on this. Lucy Russell argues that where the HWG included the Holocaust in its final cut out of "social and moral reasoning, more than historical criteria", those who had actually campaigned for its inclusion had given 
scant consideration to its "first principles" and instead focused on "winning the argument". ${ }^{95}$ Politics had been the priority; pedagogy an afterthought.

The flaws and shortfalls of the 1991 curriculum mean we must taper our assessment of how transformative it was or it could be. There is no denying its symbolism and it obviously had practical effect: the subject was now more widely taught than ever before, and there was "demand" for resources and material. ${ }^{96}$ But in lieu of government guidance there was now a vacuum where the fundamental principles of "Holocaust education" should have been. This was no mere shortcoming; it was a failing with potentially severe consequences for teaching and learning.

The chasm between ambiguous curriculum requirements and the realities of curriculum delivery were partly filled in the short-term by survivors. Since the early 1980s a growing cadre of survivors living in the United Kingdom had shown themselves willing and able to share their experiences, and to do so in educational settings. Even so, because of both interest and capacity only a minority of schoolchildren had ever had the opportunity to hear from a survivor first-hand. Similarly, though some survivors had recorded their accounts in written form, these hardly enjoyed wide cultural circulation - reflecting, in many ways, the limits of British Holocaust culture in the 1980s and early 1990s. ${ }^{97}$

The introduction of the National Curriculum did not immediately reverse these trends, but the need for resources and gaps in teachers' subject knowledge did make some more disposed to employing survivors and their stories in their teaching. Far more dramatic in its impact was the release of Schindler's List in the UK, on the back of which societal and educational interest in survivors generally underwent a huge spike. ${ }^{98}$ Yet Spielberg's film was much more than simply the stimulus for teachers to turn to survivors; it became an educational phenomenon in its own right, thanks both to its box 
office success and an initiative by the HET to put a copy of the film into every school. While these developments had enormous effect in terms of increasing interest in the subject, it was by no means without cost. Teachers' reliance on Schindler's List as a source of historical knowledge and as an "engaging" means of teaching the subject were equally problematic, having the effect of spawning a particular narrative of the Holocaust which was troublesome in its simplicity, its caricaturing of historical actors, and its sanctimonious piety. This was not solely the doing of teachers, of course; within Western culture at large these trends would only increase during the 1990s. But in England the absence of governmental steer as to how the Holocaust was to be perceived and understood meant educational activity at this time came to be guided by cultural products and propensities, the emotive and powerfully affective memories of survivors, and a small group of NGOs beginning to acquire increasing influence.

In theory, the Dearing Review of 1993-1994 presented an opportunity for this unpalatable situation to be rectified. In reality, the priority was making the curriculum more workable. With the overall goal one of "slimming down" the curriculum, working groups were formed to trim the fat of each subject's curriculum content. ${ }^{99}$ The result were new Programmes of Study, published in early 1995 with effect from that summer.

Revisions to the content of Key Stage 3 History were conducted in early 1994 within a politicised atmosphere at least as white hot as $1989-1990 .{ }^{100}$ Committed to a "dual aim of slimming and expanding the curriculum", ${ }^{101}$ the working group for history reshaped the unit housing the Holocaust into a new core Study Unit entitled "The Twentieth Century World". With this students were to acquire "an overview of some of the main events, personalities and developments during the period and how they, and total war in particular, have shaped the modern world". These included the First World 
War, "the Second World War, including the Holocaust and the dropping of the atomic bombs', and 'the legacy of the Second World War for Britain and the world". ${ }^{102}$

The preservation of the Holocaust in a streamlined curriculum was an emblematic recommitment by the Conservative government. Yet deeper discourse analysis of the stipulations also shows some noteworthy shifts in tenor. For instance, the Holocaust was no more a unit of "knowledge" or "experience of war", as per the previous curriculum, but rather a specifically framed "main event"; one apparently comparable to two global conflicts and the use of nuclear weapons. Moreover, the perceived need to provide an overview of it was not just on account of its scope, but also - it was implied - because of its "legacy" for Britain and mankind at large.

It was quite an elevation in status. Discursively it marked a sharp departure from the vagaries of 1991, suggesting the Holocaust had grown in significance during the interim. This much was true. Between the Orders for the first Programme of Study being laid before Parliament in March 1991 and the publication of the new curriculum in January 1995, a number of occurrences had indeed taken place and altered the position of the Holocaust in Britain's historical culture.

Some of these were historic world events, such as the formal reunification of Germany and creation of the European Union; others, like ethnic cleansing in Bosnia and the Rwandan genocide, bleak reminders of man's capacity for self-inflicted atrocity which, in the search for parallels and language, saw invocations of the Holocaust. There were then transcultural, mass-media events - such as looming fiftieth anniversaries of the war - and certain key Holocaust-specific occurrences, from the construction of the Beth Shalom museum-memorial and exhibitions in the Imperial War Museum, to the aforementioned success of Schindler's List. ${ }^{103}$ 
Cumulatively these substantially increased cultural interest in the Holocaust; a development that was bound to be reflected in some way in the new history curriculum. ${ }^{104}$ Though they did not constitute a cast iron guarantee the Holocaust would survive the cuts of 1994-1995, these cultural transformations - and their progressive entwinement with national and international politics - did shore up support for the project of Holocaust education. What they did not do was redress questions of rationale. The Dearing Review may have "reaffirmed the doctrine that the National Curriculum is not the whole curriculum - schools have a responsibility to transform the national curriculum into a coherent school-based plan", ${ }^{105}$ but this was no help to teachers trying to make sense of the Holocaust and teach it.

The task was made more acute by the rise in the Holocaust's cultural stock in Britain during the first half of the 1990s. Between the first and second curriculums a process of popularisation began in Britain that at once reflected and generated accumulated awareness in and familiarity with "the Holocaust". Yet this was no panacea for long-standing deficiencies in British Holocaust consciousness. Indeed, popularisation was becoming part of the problem, for with it the Holocaust as "cultural construction" was starting to emerge - an entity which by the end of the decade was becoming distinctly removed from "the historical events to which it is assumed to refer". ${ }^{106}$ This only ensured that blind spots within British cultural memory persisted: the nation's less salubrious links to the genocide remained unbeknown to most, while popular myths and misconceptions around perpetrators, victims and the so-called bystanders to the Holocaust continued to be perpetuated.

Confronting these inadequacies was the necessary first step in addressing them, but such a reckoning was neutered by an emergent discourse advocating the "lessons of the Holocaust". The history of this metanarrative is itself part and parcel of the broader 
"mnemohistory of the Holocaust". ${ }^{107}$ As Michael Marrus has recently shown, attempts to draw "early lessons" pre-dated the emergence of the definite article "the Holocaust" and subsequently gained impetus in various countries from the 1960 s onwards. ${ }^{108}$ What was distinctive in the 1990s was not the impulse to draw lessons, so much as their universal "packaging" and fierce politicisation - processes which, again, helped to unmoor the Holocaust from its historical contexts. ${ }^{109}$

These developments were caused by a conflation of factors, some not directly related to the Holocaust (such as Europeanisation post-Cold War, the rise of human rights, and fin de siècle commemorative fervour), others (like the recurrence of genocide, movements towards restitution and Holocaust-related representations) more specifically so. Education played its own, key role in this process; not just education in the shape of formal educational projects, but also education as a cultural and ever-more explicitly political exercise. In many instances, these activities were informed by what Anne Karpf would later call "the Spielberg agenda of using the Holocaust to teach liberal values": a pro-forma marked by 'sanctimony' and "platitudes". 110

For teachers required to follow a centralised curriculum but left second-guessing the intentions of the State, approaching the Holocaust as a wellspring of "universal lessons" provided a practical and tangible way forward. ${ }^{111}$ It played to existing predilections of using it as a tool for anti-racism, and it was a strategy seen to help make the past appear relevant to young people. Faced with the complexities of teaching the Holocaust, the lesson-centric approach also had much appeal for teachers. The trouble was, it was a stratagem that was anything but student-centred.

No wonder that as the new millennium approached Ruth-Anne Lenga was moved to argue "the challenge confronting educators is to search for a suitable pedagogy for Holocaust education"; one duly cognisant of "contemporary knowledge of 
how children learn, develop and grow cognitively, morally and affectively". ${ }^{112}$ It was a telling remark, one implying significant issues emerging out of the Conservative curricula remained unaddressed.

\section{The Labour curricula $-2000 \& 2007$}

The history of the Holocaust in the two Conservative curricula of the 1990s was paradoxical and contradictory. Including it within the 1991 model was unquestionably a bold move; the murder of Europe's Jews was not a natural fit for what was meant to be a Little Englander curriculum, and it did not have any real cultural traction at that time. Domestically it was a radical initiative, and internationally too: in the early 1990s, State-sponsored Holocaust education was the exception, not the norm.

Retaining the Holocaust in the streamlined 1995 curriculum sent a strong message about the value the government placed on teaching and learning. The decision to go further and actually enhance its position, suggested the government's position had changed - or, if we think of the curriculum sociologically, that the Holocaust's status within English culture had altered in key ways. Even if (as appears to be the case) the government was still no wiser about what it wanted the Holocaust in the curriculum to do, the revisions of 1995 were not possible without political will or a degree of popular assent.

By the time Labour came to power in 1997, hundreds of thousands of young people who would not otherwise have studied the Holocaust at school, had now done so. This was no mean feat, but legitimate questions about the quality and condition of this learning persisted. Structural weakness of the National Curriculum (in particular the nebulous nature of its aims and the educational ideologies which shaped how it conceived of knowledge), combined with the government's ongoing reticence to clarify the reasoning for the Holocaust's privileged position in the curriculum to have negative 
effects on teachers' attitudes and practice. In that sense, the 1995 curriculum did not solve but instead amplified inherent contradictions and inadequacies. By the same token, if the championing of Holocaust education gave the government some sense of moral authority, this was only invalidated by its foreign policy in the face of atrocities in Bosnia, Rwanda and Srebrenica. ${ }^{113}$

Inconsistencies in how the British government approached Holocaust education and how it acted in other spheres did not end with the change of administration in 1997. ${ }^{114}$ Instead this continued and was part of a more general trend in Labour's first term in power whereby the late 1990s were watermarked by distinct "aspects of continuity" in educational policy. ${ }^{115}$ This was true of both the frenzied level of policy making and also its tone, with Labour fully subscribed to interventionism and upholding (in some cases, extending) market-orientated principles. ${ }^{116}$ Where the new regime did depart from the old was in its enthusiasm for social justice, for which education was earmarked as having a utilitarian role in creating cohesion and equality. Such thinking was evident in Labour's moves towards introducing formal citizenship education in schools, with Citizenship given statutory status in 2000 and made a compulsory subject in Key Stages 3 and 4 from 2002.

The cant of Labour's belief that students' needed to be taught "rights and responsibilities in a multicultural society" was one example of an education policy riddled with incongruity. ${ }^{117}$ The government soon found "the contradictions of pursuing competitive market policies in education while affirming commitment to social justice continued to create major problems", including the challenge of remaining credible and authoritative when policies in other Whitehall departments made the government appear hypocritical and self-righteous. ${ }^{118}$ In Tomlinson's words, “notions of community cohesion, and citizenship education supposedly aimed at preparing pupils for an 
ethnically diverse society, were at odds [for example] with more punitive immigration and asylum legislation". ${ }^{119}$

This was the context for the Holocaust to continue an upward trajectory in the curriculum. Published in 1999 for implementation the following year, the third version of the National Curriculum - Curriculum 2000 - saw the most substantial changes occur within primary education (Key Stages 1 and 2). Attempts were also made to anchor the curriculum in more explicit aims, although this was rendered somewhat redundant by these being non-statutory. Nevertheless, there was a sharpening of individual subject objectives, with effect for how the Holocaust was framed. ${ }^{120}$ Now, its subject casing History - was depicted in ways which accented its capacity to develop students' appreciation for diversity and effect both attitudinal and behavioural change. ${ }^{121}$

The content of the history curriculum was again reviewed by a working party. According to Russell, the priorities given to this group were to slim the curriculum down yet further and formulate the subject's rationale, as mentioned above. However, this "did not go so far as to establish and outline the theory behind the selection of curriculum content" and meant "teachers continue[d] to lack a firm theoretical foundation for their work". ${ }^{122}$ Crucially, Russell reveals members of the group were told the Holocaust was off-limits in discussions of the Programmes of Study, since its inclusion in the curriculum had already been decided by David Blunkett, Secretary of State. $^{123}$

Central directives like this and the presence of a strong governmental hand in regards to the policy of Holocaust education had been seen before. Moreover, such was New Labour's eagerness to engage in Holocaust politics at home and abroad, that it was never likely for the Holocaust to be dropped on its watch. Far more likely was for the reverse to occur - which, in some regards, is what happened. The Holocaust remained 
in the Key Stage 3 curriculum, housed in the unit “A world study after 1900”. Through this unit students would "study some of the significant individuals, events and developments from across the twentieth century, including the two World Wars, the Holocaust, the Cold War, and their impact of Britain, Europe and the wider world". ${ }^{124}$

A subtle, but no less notable, shift in emphasis had occurred with the Holocaust moving from a "main event" of the Twentieth Century in 1995, to a "significant" event (or development, this was unclear) in 1999/2000. Of course it might well be questioned whether these four events were the most significant of the century, but this was immaterial: more telling was that these specific events - two of which were armed military conflicts, and one of which had largely been fought by proxy through the United States and NATO - had been selected. The clue to their selection was they were all postulated as having made an "impact", not just on Britain, but 'Europe and the wider world', too. What this was, was unclear but it was implied they shared common universality.

These collective changes to the History curriculum gestured to how Labour perceived the role of history and the Holocaust. In substance, this view was not wholly different to that of the 1995 curriculum, but nor was it strictly the same. There was a more direct, more assured framing in the 2000 model which reflected Labour's commitment to Holocaust politics and its confidence in just how it wished to make the Holocaust serviceable. Yet, for all this, these changes were not strikingly evident to the naked eye - partly, one might suggest, as like its predecessors Curriculum 2000 did not explicate the aims of teaching the Holocaust.

Unlike previous governments, this was not because Labour was unsure itself of what it wanted Holocaust education to do. On the contrary, six months prior to the publication of the new curriculum in November 1999 the media was awash with 
government references to learning the "lessons" of the Holocaust as the administration tried to generate consensus for its intervention in Kosovo. ${ }^{125}$ Similarly, at the same time the curriculum was launched, public consultation into the government's proposed Holocaust Remembrance Day was concluding. This initiative, some 12 months in the making, was explicit that teaching, learning, and remembering the Holocaust and its "lessons" was vital to preventing repetition and to combatting prejudice and inculcating tolerance. ${ }^{126}$ Finally, for the first time the new curriculum was accompanied by a nonstatutory exemplar Scheme of Work, produced by the government's Qualifications and Curriculum Authority (QCA). Its concern with developing chronological knowledge and conceptual understanding meant the Scheme was not without merit, but its gravitational pull towards questions of rights and responsibilities shed further light on governmental priorities and how these were influencing attitudes towards Holocaust education. ${ }^{127}$

In contrast to the Conservatives of the 1990s, Labour very much did have a vision for what teaching and learning about the Holocaust was to achieve. Understanding why it chose not to articulate this within its curriculum for school history, requires recognising Labour's larger commitment to preserving the overarching structure (and underlying precepts) of the National Curriculum - neither of which were disposed to expositions on the rationale for curriculum content. Equally important was how themes related to teaching and learning about the Holocaust were progressively being removed by the government from the confines of education policy and the educational sector. UK membership from 1998 onwards of the International Task Force for Holocaust Education, Remembrance and Research (now the International Holocaust Remembrance Alliance - IHRA), Labour's involvement in landmark international conferences related to the Holocaust in London (1997), Washington (1998) and 
Stockholm (2000), and the government's creation of Holocaust Memorial Day, all touched on Holocaust education some way, shape or form, but were developments which brought an ever increasing circle of persons and government departments into the orbit of policy formation.

Government policy and discourse on Holocaust education was therefore no longer restricted solely to the National Curriculum. Instead, it was now being forged in contexts often quite detached from the realities of the classroom, and invariably for ends that were not purely educational. To be sure there was a measure of consistency in the message - generally the Holocaust was framed as being unique and universal, a case study in evil and intolerance, and a storehouse of "lessons" on the virtues of individual agency and active citizenship. In that sense, teachers were being given cues as to how the Holocaust was to be understood and transmitted to students. But for the teacher who did not subscribe to educational essentialism or behaviourist approaches to teaching, yet was also lacking the confidence or expertise to teach the Holocaust effectively, rhetorical pronouncements by politicians "act[ing] like clerics" were not helpful. ${ }^{128}$ That the QCA created its Scheme of Work because of requests from teachers for greater guidance, proved a substantial number wanted something different from the Labour government. ${ }^{129}$

This was, of course, not the case with everyone. To those who subscribed to the notion of "lessons" and saw these as the rhyme and the reason to teach the Holocaust, Labour's policies vindicated existing practice. The government may not have invented the discourse of Holocaust education as an exercise in transmitting "lessons", but it did add "political authority and an articulated vision". ${ }^{130}$ Importantly, it was a vision in step with imaginings internationally at the turn of the $21^{\text {st }}$ Century. The Holocaust and its afterlife have always had transnational dynamics $;{ }^{131}$ but during the decade which 
straddled the coming of a new millennium the Holocaust as "universal signifier with endless connotations" acquired global scope and transnational legitimacy. ${ }^{132}$ It was not a smooth or uniform process, and it took multiple forms: transcultural phenomena such as films, literary works and the like played their part, but political will was critical and the activities of the Council of Europe, the European Union, the European Parliament, and the IHRA were instrumental.

This international institutionalisation of the Holocaust erected normative social, cultural and political frameworks which prioritised commemoration and education. The dye was cast with the Stockholm Declaration of 2000 and over the following few years the narrative framing of Holocaust remembrance and education was further expanded. So, in 2005, a European Parliament resolution on these activities made clear that "remembrance and education are vital components of the effort to make intolerance, discrimination and racism a thing of the past". ${ }^{133}$ In the same year, the United Nations Resolution 60/7 on Holocaust Remembrance Day asserted “educational programmes" could (or rather, would) "inculcate future generations with the lessons of the Holocaust in order to help prevent future acts of genocide". ${ }^{134}$

Pronouncements like these gave quasi-legal authority to the Holocaust as "a universal norm" and "global icon", positioning it as a pedagogical tool for moral instruction and civic education. ${ }^{135}$ Accounting for Labour's policies has to duly make note of this context, even if it doesn't explain the British government's particularly sanctimonious and abrasive approach to securing hegemony over the discourse of Holocaust remembrance and education. Indeed, the failure of Labour to adopt a more consensual strategy in its Holocaust politics was a major contributing factor to a heightened tensions within Britain's Holocaust culture at the turn of the millennium. ${ }^{136}$ 
As much as Labour politicians may have promoted teaching, learning and remembering the Holocaust for all the right reasons, these enterprises were always meant to serve other purposes as well. During its second and third terms, Labour's Holocaust politics were only in evermore tension with its domestic and foreign affairs. Contradiction between its immigration policies and its promotion of Holocaust consciousness were long-standing, but in the aftermath of the invasion of Iraq, the "war on terror", and increasing ethnic tensions in Britain, the government's proclivity for "Holocaust piety" left it looking duplicitous. ${ }^{137}$ In turn, public critique of Labour's Holocaust politics and the culture it had engendered only increased, with Holocaust Memorial Days often acting as annual stimuli for the expression of disquiet.

Against these developments emerged controversial rumours that some teachers were being discouraged from teaching the Holocaust for fear of offending Muslim students. Breaking in the spring of 2007, this "news" came from a "serious misreading" of a report on Teaching Emotive and Controversial History, produced by the Historical Association and commissioned by the Department for Education and Skills (DES). ${ }^{138}$ The report suggested no such thing, though it did highlight how difficult some teachers were finding teaching the Holocaust. But within a combustible atmosphere the rumours acquired purchase through the circulation of hoax emails.

Coming at a time when the National Curriculum for history was undergoing another "fundamental" review, meant the government was left flat-footed. ${ }^{139}$ In an attempt to quell rising rancour, a DES spokesman was forced to announce the Holocaust would remain compulsory in history even though the curriculum would not actually be published for another four months. ${ }^{140}$ Even then the rumours persisted, and - nearly a year later - the Secretary of State Ed Balls was forced to state "there are certain nonnegotiable subjects, which are protected in schools; one of those is the Holocaust". ${ }^{141}$ 
The fourth iteration of the National Curriculum appeared in August 2007, with effect from September 2008. As with all subjects in the new curriculum, history was, amongst other things, to enable students to become "responsible citizens who make a positive contribution to society". Meanwhile its stated "importance" was ostensibly the same as outlined in Curriculum 2000. ${ }^{142}$ Content within Key Stage 3 was yet again reduced, with discrete "units" entirely removed. In their place were "broad parameters" in which students would be taught stipulated "aspects of history" ${ }^{143}$ These "aspects" fell under just two headers: British history, and European and World History.

Within the second of these it was stated students were to learn "the changing nature of conflict and cooperation between countries and peoples and its lasting impact on national, ethnic, racial, cultural or religious issues". Students would be taught "the nature and impact of the two world wars and the Holocaust, and the role of European and international institutions in resolving conflicts". Perhaps conscious of how vague this all sounded, explanatory notes clarified "this includes studying the causes and consequences of various conflicts, including the two world wars, the Holocaust and other genocides". As to why these particular "conflicts" had been chosen, a hint lay in the general rule "the selection of conflicts should take into account their significance in terms of scale, characteristic and unique features, and immediate and longer-term impact". ${ }^{144}$

There was an inherent peculiarity to these stipulations. The depiction of the Holocaust as a "conflict" was bizarre enough, but it was a conflict seemingly devoid of either perpetrator(s) or victim(s). This rendered the Holocaust elementally abstract: not a new innovation, and in keeping with the three preceding curriculum. Indeed, just like the 2000 curriculum, the 2007 model maintained the collapsing of the two World Wars into one another, and separated them from the Holocaust. However, this detachment 
made the requirement students learn the "causes" and "consequences" of the Holocaust, its "nature" and "impact", only more, not less difficult to achieve.

An added oddity came with reference to "other genocides". Given the backlash Labour had received for creating a Holocaust rather than a Genocide Memorial Day and its subsequent inability to find a way out of the uniqueness/comparability quandary it created for itself, it is possible to read this new instruction as an exercise in realpolitik. Additional influence may have come from the establishment of the International Criminal Court earlier in the decade and growing interest among the international community in genocide prevention. ${ }^{145}$ Reference to "other genocides" was therefore explicable and, in principle, welcome. But it was an inclusion as obscure as it was instructive. Teachers were none the wiser as to what other genocides were to be covered, what conception of genocide was to be employed, or how to handle the complexities of teaching comparative genocide. Meanwhile the positioning of the phrase "other genocides" within an overarching framework characterised as "conflict", suggested a complete misunderstanding of the very nature of genocidal violence.

All told, the second Labour curriculum did nothing to resolve the long-standing, endemic issues of the previous three. By embodying continuity and change and by elevating the Holocaust whilst decontextualizing it, this version of the National Curriculum trod established paths. What distinguished this variant from its predecessors was how it managed to muddy the waters yet further. As research by the Centre for Holocaust Education revealed two years later, "some teachers" still bemoaned the National Curriculum's continued lack of clarity. In the words of one teacher, 'what does the Government want us to be teaching every child of this country? ... What aspects are they wanting us to teach? What is the focus? ${ }^{146}$ 


\section{The Coalition curriculum \& Conservative Holocaust politics -2013 to present}

That these kind of questions were being asked by teachers 16 years on from the birth of mandatory Holocaust education in England, was a damning indictment. Other findings from the Centre's teacher research in 2009 only reinforced the sense there were a raft of issues requiring urgent attention. What's more - and with all due caveats - various opinion polls and surveys conducted across the previous 10 years had intimated key problems in public knowledge and understanding of the Holocaust, including among schoolchildren. ${ }^{147}$ To make matters worse, for all the institutionalisation of Holocaust memory and education, antisemitism in British society not only persisted but persistently passed through peaks and troughs during this period - commonly in line with events in the Middle East.

The cessation of 13 years of Labour rule in 2010 and formation of a Conservative-Liberal Democrat Coalition government marked the arrival of an administration committed to a certain "cultural politics of austerity". ${ }^{148}$ In a number of policy realms there were strong echoes of the $1980 \mathrm{~s} ;{ }^{149}$ particularly in education. For instance, in its education White Paper of November 2010 there was much clamour for "a properly rounded academic education", whilst the Secretary of State, Michael Gove, was adamant it was necessary to "enact...whole-system reform in England". 150

An extensive review of the National Curriculum followed. After centring on structural issues, attention turned in 2012-2013 to formulating the content for non-Core subjects, with the guiding principles of including "essential knowledge only" and specifying "the level of detail...carefully." 151 The construction of the Programmes of Study for history were from the outset shrouded by "shadows of the 1980s", with politicians seeking to harness the subject "to foster a cohesive national identity amongst future citizens and reinforce national values through a common story and heritage". ${ }^{152}$ 
Heated debate again occurred in the public sphere thanks, in no small part, to Gove's decision to consult media-savvy historians on the development of the curriculum content. ${ }^{153}$ From the outset the formation of the new school history curriculum - no straightforward matter itself - was subsequently shot through with the politics of personality as much as anything else. Yet with the publication of the draft Programmes of Study for History in February 2013, it was apparent that perhaps the most influential personality was that of the Secretary of State himself.

Founded on the belief "a knowledge of Britain's past, and our place in the world, helps us understand the challenges of our own time", the proposed curriculum was breath-taking in the sheer weight of its content. ${ }^{154}$ Far from being rationalised, across all Key Stages reams of subjects, topics, and events were listed (most of them heavily centred on Britain). Even more extraordinary was the positioning of the Holocaust. Beneath a header "The twentieth century" appeared the listing "the Second World War". Here, following bullet-points on "the causes of appeasement", "the global reach of the war", and "the roles of Churchill, Roosevelt and Stalin", appeared the sentence "Nazi atrocities in occupied Europe and the unique evil of the Holocaust". 155 Viewed from one angle, the draft curriculum looked like a return to the Conservative curricula of the 1990s. Unlike the Labour models, the Holocaust was reconnected to the Second World War (if still somewhat separated from it). In addition, much like the 1991 model, the Holocaust was no longer framed as "event" or "conflict". However, what was dramatically different from all that had come before was its overt and highly partisan depiction. While in one respect the phrase "unique evil" upheld the trend towards abstraction, it did so to a whole new level. To employ such terminology was to either be completely ignorant of the advances made in Holocaust and genocide scholarship over the previous twenty-five years, or to self-consciously dismiss these. 
Furthermore, no justification was given for why or how the Holocaust might be described in this fashion. Instead, the Holocaust appeared as outside the realm of regular historical explanation - or, so implied, simply the work of Nazi monstrosity.

We cannot answer why the "unique evil" appellation was included, though identifying its likely origin is slightly easier. During his time as a journalist Gove used the phrase to delineate between the Holocaust and Serbian ethnic cleansing in the 1990s, and he repeated the refrain on more than one occasion once Secretary of State. ${ }^{156}$ He would continue to use the phrase long after the controversy of the new curriculum had passed and given how even those involved in the consultation claimed to not recognise the final draft Curriculum published in February, it is probable the inclusion of "unique evil" testified to his imprint more than any other. ${ }^{157}$

The draft curriculum met with a veritable tumult of criticism. Though the Holocaust did not feature within public critiques, it was raised as a matter of concern by organisations involved in Holocaust education. Notably, the government seemed to have listened to this feedback. When the final version of the curriculum was launched seven months later, there were was no reference to "Nazi atrocities" or "unique evil". This may be explained by reports that conciliation had been a conscious strategy within the Department for Education, with policymakers prepared to listen to all comments and undertake "major rewrite" of the history curriculum. ${ }^{158}$ As noble as this was, the final framing of the Holocaust that emerged was nonetheless problematic in its own right.

Distinctively Spartan in appearance, the revised 2013 history curriculum for Key Stage 3 outlined "specific aspects of content" supplemented by non-statutory examples. Prescribed content was thematic in nature, with one exception: the stipulation students be taught about "challenges for Britain, Europe and the wider world 1901 to the present day. In addition to studying the Holocaust, this could include". After this instruction 
appeared such optional content as the First World War, the inter-war period, and the Second World War. ${ }^{159}$

Like the three revisions that came before it, these terms simultaneously consolidated and reinforced existing trends and broke new ground. After yet another attempt to reduce the content of the curriculum, the Holocaust had not just been retained, but even further prioritised. There was still no clarity as to what the Holocaust was regarded as (which, for all its faults, was at least clear in the draft version of this curriculum), how it was to be taught, or to what ends. But now it was the only compulsory named event in the entire Key Stage 3 curriculum. This was, for all intents and purposes, a quite amazing development, and one with clear indication: teaching and learning about the Holocaust was regarded as simply indispensable, even more essential than the Second World War which - equally incredibly given the cultural politics of the time - was now reduced to the status of an optional topic. Just 24 years previously such an arrangement would - and indeed did - cause wholesale uproar. In 2013 this was completely reversed: not only was the curriculum distribution turned on its head, but this was met with no opposition whatsoever.

For champions of teaching and learning about the Holocaust, it was on paper an unbridled achievement. Yet the bestowal of unexplained pre-eminence was fundamentally flawed. Cut loose from any historical context, the Holocaust really did now take on the appearance of an "engorged, free floating...symbol"160 - with all the concomitant possibilities for nurturing misunderstanding and forestalling the acquisition of rigorous historical knowledge. This also did nothing to redress pedagogical approaches aimed at cultivating the "lessons" of the Holocaust in pursuit of civic-based aims; objectives that the Centre for Holocaust Education's research had shown were prevalent in schools and brought a host of complications in their train. In addition, 
though it was unlikely most teachers would choose not to find space to cover the Second World War in their curricula, the prioritisation of the Holocaust raised the possibility of teaching about that conflict being cursory or, worse still, distorting students' understandings of why it had been fought in the first place.

The Coalition's curriculum formally came into effect in September 2014, though schools were free to implement it before this date. More than two years on from its implementation, it is still too early to say with certainly whether its potentially deleterious effects will materialise. Nevertheless, the research findings from the Centre's study into students' knowledge and understanding which are discussed at length in this Special Issue do not bode well. To make matters worse, other changes within the education system over the past five years pose significant challenges to Holocaust education. Chief among these is the growth in the number of schools pursuing a collapsed Key Stage 3 curriculum (that is, delivering the entire curriculum in two years - Years 7 and 8 - rather than three), and the breakneck expansion of academies and free schools. Where one threatens the quality of teaching and learning, the other endangers the very nature of a National Curriculum, with compelling consequences for the future of Holocaust education.

\section{Summary}

Viewed in the longue durée, the position of the Holocaust in the National Curriculum acts as a porthole onto how England has (and has not) engaged with the history and memory of Europe's murdered Jews over the past generation. It is a story where education generally, and the National Curriculum specifically, has acted as a fulcrum for the institutionalisation of the Holocaust in English society and a conduit in the creation of cultural memory. 
It is of course true "'the National Curriculum' and 'the curriculum' should not be confused". Where it might be said the former "operates as a means of giving all pupils access to a common body of essential content", it may be claimed the latter "represents the totality of the experience of the child within schooling."161 Likewise, it is correct that curricula - national, or otherwise - do not teach; teachers do, and as mediators between curriculum and learner, they are potentially the most potent force in shaping educational encounters.

None of this detracts however from the very powerful role that the National Curriculum in England has played in determining the nature, form, and content of class curricula over the last quarter of a century. Through this medium successive governments have set (and, as we've seen, not set) parameters in which teachers and learners have gone about their work. As much as a conditioning force, the National Curriculum has thus set the tone for how education about the Holocaust has been perceived, understood and debated in this country since 1991. Understanding the fortunes of the Holocaust in the National Curriculum cannot of course be divorced from developments in wider culture. If, as we have seen, the history of the Holocaust in the National Curriculum is marked by change and continuity, paradox and contradiction, this can be taken as an accurate reflection of the state of the Holocaust in English historical culture, society and politics.

The National Curriculum comes to be best viewed then as something of a twoway mirror. From one side of the glass can be observed a culture and a society still struggling (and arguably, refusing) to see just how it is implicated in the history and memory of the genocide of Europe's Jews. From the other side we see a country where the importance of teaching and learning about the Holocaust appears to be continually extolled, even if few seem clear as to the whys and the wherefores or speak in the 
language of education. In the midst of all this we find politicians, NGOs and many educators eagerly (and not altogether insincerely) mouthing platitudinous "lessons", all the while apparently oblivious to how these are "not so much lessons drawn from the Holocaust as brought to it". ${ }^{162}$

As with Alice, so we are returned to a situation characterised by confusion, illogicality, and at times absurdity with no sign of resolution or clarity on the horizon. This much was apparent by how at the time the Coalition was launching its new curriculum in September 2013, the then Prime Minister David Cameron was announcing the establishment of a Holocaust Commission charged with finding ways to "preserve the memory of the Holocaust" and ensure we continue "to learn and apply the lessons of the Holocaust". ${ }^{163}$ The Commission's subsequent recommendation of a prominent new national memorial and Learning Centre, the cross-party endorsement of these proposals and commitment of $£ 50,000,000$ of public funds, and the creation of the UK Holocaust Memorial Foundation to oversee this project, has certainly opened up new possibilities and married with the prioritisation of the Holocaust seen in the Coalition's curriculum. Yet, soon after these moves took place, the Education Committee within Parliament launched a wide-ranging inquiry into the quality, impact and focus of Holocaust education and training of its educators. ${ }^{164}$

One might quite reasonably be forgiven for thinking such an inquiry would have preceded the launch of the Holocaust Commission, or at least been part of it. Then again one would not expect to find the privileging of the Holocaust in the curriculum and by the Commission co-existing alongside earnest (if ultimately aborted) moves by the Government to try to enforce academisation, and so in the process threaten statutory teaching and learning about the Holocaust. ${ }^{165}$ Such inconsistencies and peculiarities are now commonplace in England's Holocaust culture, and extend beyond education. They 
include solemn pledges made around HMD 2016 to "not stand by" all the while child refugees in Europe face repeated obstacles to finding refuge in the British Isles; peers holding meetings in the House of Lords where Jews "were blamed for the Holocaust" at the same time that swathes of British men and women descended from inter-war refugees decide to take up their right to apply for German citizenship; ${ }^{166}$ and, of course, all this takes place against the backcloth of the dramatic spike in racist incidents and ethnic tensions in the aftermath of Brexit - a development which surely calls into question Britain's status as a paragon of Holocaust education and remembrance. In gazing through the Looking Glass and being confronted with this situation, one is but reminded of Alice's other question to the Cheshire Cat:

\footnotetext{
"what sort of people live about here?"

"In that direction," the Cat said, waving its right paw round, "lives a Hatter: and in that direction," waving the other paw, "lives a March Hare. Visit either you like: they are both mad." 167
}

\section{Acknowledgements}

With much thanks and love to Anna and Sören, for their patience and understanding.

\section{Notes}

${ }^{1}$ Carroll, The Annotated Alice, 67.

${ }^{2}$ Pearce, Holocaust Consciousness. Whilst it is certainly legitimate to use the registers of "Britain" and the "United Kingdom" when discussing Holocaust consciousness, there are occasions when greater specificity is required - as this article, with its focus on education, aptly demonstrates. Indeed, we may fast be reaching a time when this is essential across the 
board, for should the movement towards Scottish independence ultimately prove successful, it will be necessary to further distinguish between the ways the Holocaust is approached within the different nations of the British Isles.

${ }^{3}$ The National Curriculum, as mandated by the 1988 Education Act, was to be delivered within England and Wales. Northern Ireland introduced a National Curriculum in 1992 which contained many of the features of the English and Welsh curriculum, but had some differences. Scotland - which has always had a measure of independence on educational affairs - has never followed the National Curriculum.

${ }^{4}$ There is no single, uniform education system within the United Kingdom. Rather, each of its constituent parts - England, Wales, Northern Ireland and Scotland - have their own education departments, which are funded and organised separately.

${ }^{5}$ Pearce, "When the National Curriculum is not compulsory."

${ }^{6}$ Department for Education, "Written Evidence Submitted by the Department for Education."

${ }^{7}$ Marrus, Lessons of the Holocaust, 39.

${ }^{8}$ Barnett, Higher Education, 1.

${ }^{9}$ Foster, et al. What do students know and understand about the Holocaust?

${ }^{10}$ Pettigrew, et al. Teaching about the Holocaust in English Secondary Schools, 77-78, 89-90.

${ }^{11}$ Holocaust Educational Trust, Exploring the Holocaust, 6; House of Commons Education Committee, Holocaust education, 3 .

${ }^{12}$ Pettigrew et al., Teaching about the Holocaust: 90-91, 104.

${ }^{13}$ Ibid., 76, 82-83.

${ }^{14}$ Schweber \& Findling, Teaching the Holocaust, 2; Langer, Admitting the Holocaust, 3; Salmons, “Teaching or Preaching?”, 141.

${ }^{15}$ Cesarani, Final Solution, xxix.

${ }^{16}$ Pring, The New Curriculum, 2.

${ }^{17}$ Kelly, The Curriculum: Theory and Practice, 11.

${ }^{18}$ Apple, Ideology and Curriculum, 13. 
${ }^{19}$ Lawton, Class, Culture and the Curriculum, 6.

${ }^{20}$ Lawton, "Preface" to The Politics of the School Curriculum, vii.

${ }^{21}$ Lawton, Education, Culture and the National Curriculum, 17.

${ }^{22}$ Martin, Education Reconfigured, 113.

${ }^{23}$ Bernstein, Class Codes and Control-Volume I, 156.

${ }^{24}$ Ibid., 165-166.

${ }^{25}$ Popkewitz, "The Production of Reason and Power," 152.

${ }^{26}$ Apple, Official Knowledge, 10.

${ }^{27}$ Young, "What is a curriculum and what can it do?" 7.

${ }^{28}$ Young, "Curriculum theory and the question of knowledge" 827

${ }^{29}$ Silcock, New Progressivism, 23-24.

${ }^{30}$ Lawton, Education, Culture and the National Curriculum, 4; Silcock, New Progressivism, 24.

${ }^{31}$ Lawton, Education, Culture and the National Curriculum, 4.

${ }^{32}$ Pring, The New Curriculum, 99.

${ }^{33}$ Lawton, Education, Culture and the National Curriculum, 5.

${ }^{34}$ Pring, The New Curriculum, 99.

${ }^{35}$ Lawton, Education, Culture and the National Curriculum, 5.

${ }^{36}$ Pring, The New Curriculum, 100.

${ }^{37}$ White, "Introduction", 6.

${ }^{38}$ Aldrich, "Introduction", 1.

${ }^{39}$ Tomlinson, Education in a post-welfare society, 13-18.

${ }^{40}$ Dale, The State and Education Policy, 98.

${ }^{41}$ Chitty, Education Policy in Britain, 23.

${ }^{42}$ Ball, Politics and Policy-making in Education, 23-26.

${ }^{43}$ Tomlinson, Education in a post-welfare society, 20-23.

${ }^{44}$ Ball, Politics and Policy-Making, 24. 
${ }^{45}$ Tomlinson, Education in a post-welfare society, 32.

${ }^{46}$ Dale, The State and Education Policy, 132-133.

${ }^{47}$ Education Reform Act 1988, 2.

${ }^{48}$ Lawton, Education, Culture and the National Curriculum, 45.

${ }^{49}$ Graybill, "Hermeneutics and education",149.

${ }^{50}$ Aldrich, "A Curriculum for the Nation”, 132.

${ }^{51}$ Kelly, The National Curriculum, 72.

${ }^{52}$ Graybill, "Hermeneutics and education", 154.

${ }^{53}$ Crawford, "The History of the Right", 438

${ }^{54}$ White, "Introduction", 2. See also White, "The Aims of Education in the Liberal Democratic State" 103-105.

${ }^{55}$ Griffith, National Curriculum: National Disaster? xvi-xvii.

${ }^{56}$ Slater, The Politics of History Teaching, 1; Phillips, "Government Policies, the State and the Teaching of History", 12.

${ }^{57}$ See Kushner, The Holocaust and the Liberal Imagination; Pearce, "The Development of Holocaust Consciousness in Contemporary Britain”, 71-94.

${ }^{58}$ Assmann, Shadows of Trauma, 5; Gumbrecht, After 1945. See also Cesarani \& Sundquist, eds., After the Holocaust.

${ }^{59}$ Giroux, Border Crossings.

${ }^{60}$ Kushner, The Holocaust and the Liberal Imagination.

${ }^{61}$ Smith, Genocide and the Europeans, 5-7. 99.

${ }^{62}$ Heerten \& Moses, "The Nigerian-Biafra war: Postcolonial conflict and the question of genocide”, 180. Also Smith, "The UK and 'genocide' in Biafra", 16:2-3, 251.

${ }^{63}$ Smith, Genocide and the Europeans, 3, 6.

${ }^{64}$ Pearce, Holocaust Consciousness, 47-50; Russell, Teaching the Holocaust, 62-64.

${ }^{65}$ Fox, Teaching the Holocaust, 9, 62-63.

${ }^{66}$ Ibid., 13. 
${ }^{67}$ Pearce, Holocaust Consciousness, 53.

${ }^{68}$ Hector, "Teaching the Holocaust in England", 104.

${ }^{69}$ Fox, Teaching the Holocaust, 5-6.

${ }^{70}$ Keating \& Sheldon, "History in Education" 12.

${ }^{71}$ Cannadine, Keating, Sheldon, The Right Kind of History, 194.

${ }^{72}$ Cesarani, Justice Delayed; Russell, Teaching the Holocaust, 71-73.

${ }^{73}$ Prochaska, "The History Working Group: Reflections and Diary," 87.

${ }^{74}$ Ibid., 87-88; Guyver, "The History Working Group and Beyond: A Case Study in the UK's History Quarrels", 165.

${ }^{75}$ Russell, Teaching the Holocaust, 89-93.

${ }^{76}$ Kushner, The Holocaust and the Liberal Imagination, 262.

${ }^{77}$ Berman, Holocaust Agendas, Conspiracies and Industries? 28.

${ }^{78}$ Janner, Marshall, Rhodes James, Rooker, "Submission on the Teaching of the Second World War and the Rise and Fall of Nazi Germany in the National Curriculum".

${ }^{79}$ Russell, Teaching the Holocaust, 100-102; Pearce, Holocaust Consciousness, 57-58.

${ }^{80}$ Russell, Teaching the Holocaust, 97-102.

${ }^{81}$ National Curriculum History Working Group, Final Report, 98-99.

${ }^{82}$ See Department of Education and Science, History for ages 5 to 16; National Curriculum Council, National Curriculum Council Consultation Report.

${ }^{83}$ Cannadine, Keating, Sheldon, The Right Kind of History, 197.

${ }^{84}$ Fox, "Explaining the ultimate inhumanity".

${ }^{85}$ Klein, "Facing up to the Final Solution"; Fox, "Explaining the ultimate inhumanity".

${ }^{86}$ Short, "The Holocaust in the National Curriculum", 172.

${ }^{87}$ Ibid. 178.

${ }^{88}$ Ibid. 186.

${ }^{89}$ Pearson, "ICT in the National Curriculum - Revised but not Resolved", 200.

${ }^{90}$ Department for Education and Science, History in the National Curriculum, 45. 
${ }^{91}$ National Curriculum History Working Group, Final Report, 99. Within history education substantive concepts are regarded as 'a phenomenon that recurs in different contexts in the past'. Substantive concepts are a constituent part of substantive knowledge in history; that is, history's content. Substantive knowledge is to be distinguished from procedural knowledge, which is concerned not with the "stuff" of history, but with the disciplinary concepts which help to process and make sense of history. See here Fordham, "Knowledge and Language", 44. Also, see Lee \& Ashby, "Progression in Historical Understanding", 199-222.

${ }^{92}$ Lawton, Beyond the National Curriculum, 5.

${ }^{93}$ Graybill, "Hermeneutics and education", 150.

${ }^{94}$ Lawton, Beyond the National Curriculum, 71.

${ }^{95}$ Russell, Teaching the Holocaust, 106-107.

${ }^{96}$ Berman, Holocaust Agendas, Conspiracies and Industries? 29.

${ }^{97}$ This also reflects differences in the rate at which the "rise of the survivor" occurred in Britain and, say, North America. In this regard we again see the need to temper grand narratives about the course of post-war Holocaust consciousness in the Western world, and recognise the need for nuance when speaking of general trajectories across nations. See here Shandler, While America Watches, 183-211.

${ }^{98}$ Pearce, Holocaust Consciousness, 65-67.

${ }^{99}$ Chitty, Education Policy in Britain, xv; Cannadine, Keating, Sheldon, The Right Kind of History, 200.

${ }^{100}$ Russell, Teaching the Holocaust, 110-112.

${ }^{101}$ Ibid., 112.

${ }^{102}$ Department for Education, History in the National Curriculum, 13.

${ }^{103}$ Pearce, Holocaust Consciousness, 96-104; 186-196.

${ }^{104}$ Martin, Education Reconfigured, 106.

${ }^{105}$ Lawton, Beyond the National Curriculum, 96-97.

${ }^{106}$ Cesarani, Final Solution, xxvii. 
${ }^{107}$ Assmann, "The Holocaust - a Global Memory?" 98.

${ }^{108}$ Marrus, Lessons of the Holocaust, 52-82.

${ }^{109}$ Ibid., 152.

${ }^{110}$ Karpf, "Memories Aren’t made of this".

${ }^{111}$ Marrus, Lessons of the Holocaust, 137-160

${ }^{112}$ Lenga, "Holocaust education”, 53-54.

${ }^{113}$ Cameron, Britain's Hidden Role; Simms, Unfinest Hour.

${ }^{114}$ Levene, "Britain’s Holocaust Memorial Day", 26-59.

${ }^{115}$ Chitty, Education Policy in Britain, 58.

${ }^{116}$ Tomlinson, Education in a Post-Welfare Society, 90.

${ }^{117}$ Tomlinson, Race and Education, 128.

118 Tomlinson, Education in a Post-Welfare Society, 91.

${ }^{119}$ Tomlinson, Race and Education, 134.

${ }^{120}$ White, "Introduction" 1-2; Lawton, Education and Labour Party Ideologies, 128.

${ }^{121}$ Department for Education and Employment, The National Curriculum for England: History, 14.

${ }^{122}$ Russell, Teaching the Holocaust, 120.

${ }^{123}$ Ibid. 120-121.

${ }^{124}$ Ibid. 22.

${ }^{125}$ Pearce, Holocaust Consciousness, 141-143.

${ }^{126}$ Home Office, Government Proposal for a Holocaust Remembrance Day.

${ }^{127}$ Qualifications and Curriculum Authority, "Unit 19: How and why did the Holocaust happen?'

${ }^{128}$ Buruma, "Yes, acts of barbarism should be remembered".

${ }^{129}$ Russell, Teaching the Holocaust, 129.

${ }^{130}$ Pearce, Holocaust Consciousness, 83.

${ }^{131}$ Assmann, "The Holocaust - a Global Memory?”, 99. 
${ }^{132}$ Szejnmann \& Davies, "Introduction: How the Holocaust Looks Now", xxiii.

133 "European Parliament resolution on remembrance of the Holocaust, antisemitism and racism”.

134 "Resolution adopted by the General Assembly on the Holocaust Remembrance".

${ }^{135}$ Assmann, "The Holocaust - a Global Memory?", 105-112.

${ }^{136}$ Pearce, Holocaust Consciousness, 186-209.

${ }^{137}$ Rose, Mourning Becomes the Law, 43.

${ }^{138}$ The Historical Association, "The T.E.A.C.H. Report".

${ }^{139}$ Cannadine, Keating, Sheldon, The Right Kind of History, 201.

${ }^{140}$ BBC News, "Holocaust "ban' email confusion".

${ }^{141}$ BBC News, "UK government acts on hoax email".

${ }^{142}$ Department for Children, Schools and Families \& the Qualifications and Curriculum Authority, The National Curriculum, 111.

${ }^{143}$ Ibid. 115.

${ }^{144}$ Ibid., 116.

${ }^{145}$ Smith, Genocide and the Europeans, 62.

${ }^{146}$ Pettigrew et al, Teaching the Holocaust, 89.

${ }^{147}$ Pearce, Holocaust Consciousness, 225.

${ }^{148}$ Bramall, The Cultural Politics of Austerity.

${ }^{149}$ Wright, On Living in an Old Country, 24-26, 37-44.

${ }^{150}$ Department for Education, The Importance of Teaching, 44, 7.

${ }^{151}$ Department for Education, The Framework for the National Curriculum, 23.

${ }^{152}$ Sheldon, "Politicians and History", 269.

${ }^{153}$ Guyver, "The role of government in determining the school curriculum".

${ }^{154}$ Department for Education, The National Curriculum in England, 165.

${ }^{155}$ Ibid. 171. 
${ }^{156}$ Gove, "Speaking up for the Serbs"; Rosen, "Gove vows to keep funding Auschwitz trips";

Gove, Hansard, Column 18; Rashty, "Gove praises Anne Frank Trust”.

${ }^{157}$ Gove, "The necessity of memory"; Boffey, "Historians attack Michael Gove".

${ }^{158}$ Mansell, "Michael Gove redrafts new history curriculum after outcry".

${ }^{159}$ Department for Education, History Programmes of Study: Key Stage 3, 2-4.

${ }^{160}$ Alexander, "The Social Construction of Moral Universals", 52.

${ }^{161}$ Oates, "Could do better", 133.

${ }^{162}$ Novick, The Holocaust in American Life, 242.

${ }^{163}$ Cameron, "Prime Minister's Speech".

${ }^{164}$ House of Commons Education Committee, Holocaust education.

${ }^{165}$ BBC News, "Government formally drops academies legislation".

166 The Guardian, “Jenny Tonge quits Lib Dems"; The Guardian, "Descendants of Jewish refugees".

${ }^{167}$ Carroll, The Annotated Alice, 67.

\section{References}

Alexander, Jeffrey C. "The Social Construction of Moral Universals.” In Remembering the Holocaust: A Debate. Oxford: Oxford University Press, 2009.

Aldrich, Richard. "A Curriculum for the Nation." In Lessons from History of Education: The Selected Works of Richard Aldrich. London \& New York: Routledge, 2006. Aldrich, Richard. "Introduction". In History in the National Curriculum, edited by Richard Aldrich. London: Institute of Education, 1991.

Apple, Michael W. Official Knowledge: Democratic Education in a Conservative Age, Third Edition. New York \& London: Routledge, 2014.

Apple, Michael W. Ideology and Curriculum. Third Edition. New York \& London: RoutledgeFalmer, 2004.

Assmann, Aleida. Shadows of Trauma: Memory and the Politics of Postwar Identity, Trans. Sarah Clift. New York: Fordham University Press, 2016. 
Assmann, Aleida. “The Holocaust - a Global Memory? Extensions and Limits of a New Memory Community". In Memory in a Global Age: Discourses, Practices and Trajectories, edited by Aleida Assmann \& Sebastian Conrad. Basingstoke: Palgrave Macmillan, 2010.

Ball, Stephen J. Politics and Policy-making in Education: Explorations in Policy Sociology. London: Routledge, 1990.

Barnett, Ronald. Higher Education: A Critical Business. Buckingham: Open University Press, 1997.

BBC News. "Government formally drops academies legislation." October 27, 2016. Available via: http://www.bbc.co.uk/news/education-37791282.

BBC News. "UK government acts on hoax email.” February 4, 2008. Available via: http://news.bbc.co.uk/1/hi/education/7226778.stm.

BBC News. “Holocaust ‘ban' email confusion.” April 17, 2007. Available via: http://news.bbc.co.uk/1/hi/education/6563429.stm.

Berman, Judith. Holocaust Agendas, Conspiracies and Industries? Issues and Debates in Holocaust Memorialization. London: Vallentine Mitchell, 2006.

Bernstein, Basil. Class Codes and Control-Volume I: Theoretical Studies Towards a Sociology of Language. New York \& London: Routledge, 2003.

Boffey, Daniel. "Historians attack Michael Gove over 'narrow' curriculum.” The Observer, February 17, 2013.

Bramall, Rebecca. The Cultural Politics of Austerity: Past and Present in Austere Times. Basingstoke: Palgrave Macmillan, 2013.

Buruma, Ian. "Yes, acts of barbarism should be remembered, but I'm still against Holocaust Day.” The Guardian, January 29, 2002.

Cameron, David. " $25^{\text {th }}$ Anniversary of the Holocaust Educational Trust: Prime Minister's Speech”, September 16, 2013. Available via: https://www.gov.uk/government/speeches/25th-anniversary-of-the-holocausteducational-trust-prime-ministers-speech.

Cameron, Hazel. Britain's Hidden Role in the Rwandan Genocide - The Cat's Paw. Abingdon: Routledge, 2013.

Cannadine, David, Jenny Keating, Nicola Sheldon. The Right Kind of History: Teaching the Past in Twentieth-Century England. Basingstoke: Palgrave Macmillan, 2011. 
Carroll, Lewis. The Annotated Alice: The Definitive Edition, ed Martin Gardner. London: Penguin, 2001.

Cesarani, David. Final Solution: The Fate of the Jews 1933-49. London: Macmillan, 2016.

Cesarani, David. Justice Delayed: How Britain Became a Refuge for Nazi War Criminals. London: Phoenix Press, 2000.

Cesarani, David and Eric J. Sundquist. Eds., After the Holocaust: Challenging the Myth of Silence. London \& New York: Routledge, 2012.

Chitty, Clyde. Education Policy in Britain. Second Edition. Basingstoke: Palgrave Macmillan, 2009.

Crawford, Keith. "The Hisotry of the Right: The Battle for Control of National Curriculum History, 1989-1994.” British Journal of Educational Studies, 43:4 (1995).

Dale, Roger. The State and Education Policy. Milton Keynes: Open University Press, 1989.

Department for Children, Schools and Families \& the Qualifications and Curriculum Authority, The National Curriculum: Statutory Requirements for Key Stages 3 and 4. London: HMSO, 2007.

Department for Education, "Written Evidence Submitted by the Department for Education”. Education Committee Inquiry into Holocaust Education, HOL0053. Available via: http://www.parliament.uk/business/committees/committees-a-z/commonsselect/education-committee/inquiries/parliament-2015/holocaust-education-1516/publications/.

Department for Education, History Programmes of Study: Key Stage 3. London: HMSO, 2013.

Department for Education, The National Curriculum in England: Framework document for consultation, February 2013. London: HMSO, 2013.

Department for Education, The Framework for the National Curriculum: A report by the Expert Panel for the National Curriculum Review. London: HMSO, 2011.

Department for Education. The Importance of Teaching: The Schools White Paper. London: HMSO, 2010. 
Department for Education. History in the National Curriculum. London: HMSO, 1995. Department for Education and Employment. The National Curriculum for England: History. London: HMSO, 1999.

Department for Education and Science. History in the National Curriculum (England). London: HMSO, 1991.

Department of Education and Science. History for ages 5 to 16: Proposals of the Secretary of State for Education and Science. London: HMSO, 1990.

Education Reform Act 1988, Chapter 40: Vol 1/2, Reprint. London: HMSO, 1989. Fordham, Michael. "Knowledge and Language: Beyond Historical with Substantive Concepts". In Masterclass in History Education: Transforming Teaching and Learning, edited by Christine Counsell, Katherine Burn, and Arthur Chapman. London: Bloomsbury Academic, 2016.

Foster, Stuart J., Alice Pettigrew, Andy Pearce, Rebecca Hale, Adrian Burgess, Paul Salmons and Ruth-Anne Lenga. What do students know and understand about the Holocaust? Evidence from English Secondary schools. Second Edition. London: UCL Centre for Holocaust Education, 2016.

Fox, John P. Teaching the Holocaust: A Report of a Survey in the United Kingdom.

Leicester: The National Yad Vashem Charitable Trust \& the Centre for Holocaust Studies, University of Leicester, 1989.

Fox, Sue. "Explaining the ultimate inhumanity.” The Times, December 7, 1992.

Giroux, Henry A. Border Crossings: Cultural Workers and the Politics of Education. Second Edition. New York \& London: Routledge, 2005.

Gove, Michael. “"The necessity of memory': Full text of Michael Gove's speech to the Holocaust Educational Trust", September 10, 2014. Available via: http://www.conservativehome.com/platform/2014/09/the-necessity-of-memorythe-full-text-of-michael-goves-speech-to-the-holocaust-educational-trust.html.

Gove, Michael. Hansard, House of Commons Debates, Column 18, October 11, 2010. Gove, Michael. "Speaking up for the Serbs.” The Times, October 13, 1998.

Graybill, E. "Hermeneutics and education: The case for an emergent criticism." In Curriculum Studies: Curriculum Knowledge, edited by David Scott. Abingdon, Oxon: RoutledgeFalmer, 2003. 
Griffith, Rhys. National Curriculum: National Disaster? Education and Citizenship. London \& New York: Routledge, 2000.

The Guardian. "Jenny Tonge quits Lib Dems after suspension for alleged antisemitic comments". October 27, 2016. Available via:

https://www.theguardian.com/politics/2016/oct/27/jenny-tonge-quits-lib-demsafter-suspension-for-alleged-antisemitic-comments.

The Guardian. "Descendants of Jewish refugees seek German citizenship after Brexit vote". October 30, 2016. Available via: https://www.theguardian.com/world/2016/oct/30/uk-descendants-of-jewishrefugees-seek-german-citizenship-after-brexit-vote.

Gumbrecht, Hans Ulrich. After 1945: Latency as Origin of the Present. Stanford: Stanford University Press, 2013.

Guyver, Robert. "The History Working Group and Beyond: A Case Study in the UK's History Quarrels." In History Wars and the Classroom: Global Perpsectives, edited by Tony Taylor and Robert Guyver. Charlotte, North Carolina: Information Age Publishing, 2012.

Guyver, Robert. "The role of government in determining the school history curriculum: Lessons from Australia." History and Policy, April 11, 2011. Available via: http://www.historyandpolicy.org/policy-papers/papers/the-role-of-governmentin-determining-the-school-history-curriculum-lessons.

Hector, Susan. "Teaching the Holocaust in England." In Teaching The Holocaust: Educational Dimensions, Principles and Practice, edited by Ian Davies. London: Continuum, 2000.

Historical Association. “The T.E.A.C.H. Report.” September 4, 2007. Available via: http://www.history.org.uk/resources/resource 780.html.

Holocaust Educational Trust. Exploring the Holocaust - A Cross-Curricular Scheme of Work for Key Stages 2 \& 3: Teachers' Guide. London: Holocaust Educational Trust, 2014.

Home Office, Government Proposal for a Holocaust Remembrance Day (London: HMSO, 1999

House of Commons Education Committee. Holocaust education: Second Report of Session 2015-16. London: HMSO, 2016. 
Janner, Greville, John Marshall, Robert Rhodes James, and Jeff Rooker. "Submission on the Teaching of the Second World War and the Rise and Fall of Nazi Germany in the National Curriculum.”, Board of Deputies Archive, $\mathrm{ACC} / 3121 / \mathrm{C} 8 / 2 / 16$.

Karpf, Anne. "Memories Aren't made of this.” The Guardian, January 26, 2001.

Keating, Jenny and Nicola Sheldon. "History in Education: Trends and themes in history teaching, 1900-2010." In Debates in History Teaching, edited by Ian Davies. London \& New York: Routledge, 2011.

Kelly, A.V. The Curriculum: Theory and Practice. Sixth Edition. London: Sage Publications, 2009.

Klein, Reva. "Facing up to the Final Solution.” Times Educational Supplement, April 17, 1992.

Kushner, Tony. The Holocaust and the Liberal Imagination: A Social and Cultural History. Oxford: Blackwell, 1994.

Langer, Lawrence. Admitting the Holocaust: Collected Essays (Oxford: Oxford University Press, 1995).

Lawton, Denis. Class, Culture and the Curriculum. Abingdon, Oxon: Routledge, 2012.

Lawton, Denis. Education and Labour Party Ideologies: 1900-2001. Oxon:

RoutledgeFalmer, 2005.

Lawton, Denis. Beyond the National Curriculum: Teacher Professionalism and Empowerment. London: Hodder \& Staughton, 1996.

Lawton, Denis. Education, Culture and the National Curriculum. London: Hodder \& Stoughton, 1989.

Lawton, Denis. "Preface" to The Politics of the School Curriculum. London, Boston \& Henley: Routledge \& Kegan Paul, 1980.

Lee, Peter and Ashby, Ros. "Progression in Historical Understanding among Students Ages 7-14". In Knowing Teaching \& Learning History, edited by Peter N. Stearns, Peter Seixas and Sam Wineburg. New York and London: New York University Press, 2000.

Lenga, Ruth-Anne. "Holocaust education: The search for a suitable pedagogy." The Journal of Holocaust Education, 7:3 (1998). 
Levene, Mark. “Britain's Holocaust Memorial Day: A Case of Post-Cold War WishFulfilment, or Brazen Hypocrisy?" Human Rights Review, 7:3 (2006): 26-59.

Mansell, Warwick. "Michael Gove redrafts new history curriculum after outcry." The Guardian, June 21, 2013.

Marrus, Michael R. Lessons of the Holocaust. Toronto: University of Toronto Press, 2016.

Martin, Jane Roland. Education Reconfigured: Culture, Encounter and Change. New York: Routledge, 2011.

National Curriculum Council, National Curriculum Council Consultation Report: History (London: HMSO, 1990).

National Curriculum History Working Group. Final Report. London: HMSO, 1990.

Novick, Peter. The Holocaust in American Life. Boston, New York. Mariner Books, 2000.

Oates, Tim. "Could do better: Using international comparisons to refine the National Curriculum in England." The Curriculum Journal, 22:2 (2011).

Pearce, Andy. Holocaust Consciousness in Contemporary Britain. London \& New York: Routledge, 2014.

Pearce, Andy. "When the National Curriculum is not compulsory, we need to keep presenting the case for Holocaust education”. UCL Institute of Education Blog, July 3, 2014. Available via:

https://ioelondonblog.wordpress.com/2014/07/03/when-the-national-curriculumis-not-compulsory-we-need-to-keep-presenting-the-case-for-holocausteducation/.

Pearce, Andy. "The Development of Holocaust Consciousness in Contemporary Britain, 1979-2001". Holocaust Studies: A Journal of Culture and History, 14:2 (2008).

Pearson, Matthew. "ICT in the National Curriculum - Revised but not Resolved." In The National Curriculum and its Effects, edited by Cedric Cullingford and Paul Oliver. Aldershot: Ashgate, 2001.

Pettigrew, Alice, Stuart J. Foster, Jonathan Howson, Paul Salmons, Ruth-Anne Lenga, Kay Andrews. Teaching about the Holocaust in English Secondary Schools: An Empirical Study of National Trends, Perspectives and Practice. London:

Institute of Education, 2009. 
Phillips, Robert. "Government Policies, the State and the Teaching of History.” In Issues in History Teaching, edited by James Arthur and Robert Phillips. London: Routledge, 2000.

Popkewitz, Thomas S. "The Production of Reason and Power: Curriculum History and Intellectual Traditions." In Cultural History and Education: Critical Essays on Knowledge and Schooling, edited by Thomas S. Popkewitz, Barry M. Franklin, Miguel A. Pereyra. New York: RoutledgeFarmer, 2001.

Pring, Richard. The New Curriculum. London: Cassell Educational Limited, 1989. Qualifications and Curriculum Authority. 'Unit 19: How and why did the Holocaust happen?', available via:

http://webarchive.nationalarchives.gov.uk/20090608182316/http://standards.dfe s.gov.uk/pdf/secondaryschemes/his19.pdf.

Prochaska, Alice. "The History Working Group: Reflections and Diary.” History Workshop Journal, 30 (1990).

Rashty, Sandy. “Gove praises Anne Frank Trust”. Jewish Chronicle, February 11, 2013. Resolution adopted by the General Assembly on the Holocaust Remembrance (A/RES/60/7, 1 November 2005). Available via: http://www.un.org/en/holocaustremembrance/docs/res607.shtml.

Rose, Gillian. Mourning Becomes the Law: Philosophy and Representation. Cambridge: Cambridge University Press, 1996.

Rosen, Robyn. "Gove vows to keep funding Auschwitz trips.” Jewish Chronicle, July 1, 2010.

Russell, Lucy. Teaching the Holocaust in School History: Teachers or Preachers? London: Continuum, 2006.

Salmons, Paul. "Teaching or Preaching? The Holocaust and Intercultural Education in the UK". Intercultural Education, 14:2 (2003),

Schweber, Simone, and Debbie Findling, Teaching the Holocaust. Los Angeles: Torah Aura Productions, 2007.

Shandler, Jeffrey. While America Watches: Televising the Holocaust. Oxford: Oxford University Press, 1999.

Sheldon, Nicola. "Politicians and History: The National Curriculum, National Identity and the Revival of the National Narrative." History (2012). 
Short, Geoffrey. "The Holocaust in the National Curriculum: A Survey of Teachers' Attitudes and Practices." Journal of Holocaust Education, 4:2 (1995).

Silcock, Peter. New Progressivism. London: Falmer Press, 1999.

Simms, Brendan. Unfinest Hour: Britain and the Destruction of Bosnia. London: Penguin, 2001.

Slater, John. The Politics of History Teaching: A Humanity Dehumanised. London: Institute of Education, 1989.

Smith, Karen E. "The UK and 'genocide' in Biafra." Journal of Genocide Research, (2014), 16:2-3.

Smith, Karen E. Genocide and the Europeans. Cambridge: Cambridge University Press, 2010.

Szejnmann, Claus-Christian W. and Martin L. Davies. "Introduction: How the Holocaust Looks Now." In How the Holocaust Looks Now: International Perspectives, edited by Martin L. Davies and Claus-Christian W. Szejnmann. Basingstoke: Palgrave Macmillan, 2007.

Tomlinson, Sally. Race and Education: Policy and Politics in Britain. Berkshire: Open University Press, 2008.

Tomlinson, Sally. Education in a post-welfare society. Second Edition. Berkshire: Open University Press, 2005.

White, John. The Invention of the Secondary Curriculum. New York: Palgrave Macmillan, 2011.

White, John. "The Aims of Education in the Liberal Democratic State." In The Curriculum and the Child: The Selected Works of John White. London \& New York: Routledge, 2005.

White, John. "Introduction". In Rethinking the School Curriculum: Values, aims and purposes, edited by John White. London \& New York: Routledge Falmer, 2004.

Wright, Patrick. On Living in an Old Country: The National Past in Contemporary Britain. OUP Edition. Oxford: Oxford University Press, 2009.

Young, Michael. "What is a curriculum and what can it do?" The Curriculum Journal, 25:1 (2014).

Young, Michael. "Curriculum theory and the question of knowledge: a response to the six papers.” Journal of Curriculum Studies, 47:6 (2015). 
$\longrightarrow$ 